\title{
RISK MANAGEMENT AS INCREASED CORPORATE GOVERNANCE REQUIREMENT IN ITALIAN BANKS AND INSURANCE COMPANIES
}

\author{
Rosaria Cerrone *
}

* Department of Management and Innovation Systems, University of Salerno, Italy Contact details: University of Salerno, Via Giovanni Paolo II, 132 - 84084 Fisciano (SA), Italy

\section{OPEN ACCESS}

How to cite this paper: Cerrone, R. (2019). Risk management as increased corporate governance requirement in Italian banks and insurance companies. Corporate Board: Role, Duties and Composition, 15(3), 58-69. https://doi.org/10.22495/cbv15i3art5

Copyright $@ 2019$ The Author

This work is licensed under a Creative Commons Attribution 4.0 International License (CC BY 4.0).

https://creativecommons.org/licenses/by 14.0/

ISSN Online: 2312-2722

ISSN Print: 1810-8601

Received: 22.09 .2019

Accepted: 13.12 .2019

JEL Classification: G21, G22, G32, K23 DOI: $10.22495 / \mathrm{cbv} 15 i 3 a r t 5$

\begin{abstract}
The paper explores how risk management and internal audit functions can be used effectively to strengthen governance frameworks and ensure compliance with new regulatory requirements in the financial services industry. The aim of the paper is the description of the regulatory framework which gives great relevance to risk management both in banks and in insurance companies. A right and efficient risk management scheme, in fact, is based on efficient corporate governance of the financial intermediary. Better corporate governance ensures the achievement of risk management principles. For this, the paper explores the organizational and governance structure of financial intermediaries. The paper is a timely addition to the current discussion around the relevance of sound governance for banks and insurance. It extends the effort to evaluate risk governance standards at these financial intermediaries against regulatory requirements. The paper comes to the conclusion that risk mitigation as the process of reducing risk exposure and minimizing the likelihood of an incident needs to be continually addressed to ensure the business is fully protected and this aim is reached by linking controls to risks, activities, policies, and procedures and to track their effectiveness.
\end{abstract}

Keywords: Risk Management, Corporate Governance, Insurance Industry, Solvency II, Banks

Authors' individual contributions: The author is responsible for all the contributions to the paper according to CRediT (Contributor Roles Taxonomy) standards.

\section{INTRODUCTION}

As financial institutions whose business is the acceptance and management of risk, banks and insurance companies are expected to have sound governance practices and effective risk management systems. The nature of their business activities requires banks and insurers to be subject to tailored guidance on their risks and responsibilities.

The governance structure should have an appropriate allocation of oversight and administrative responsibilities, stipulate and delineate clearly the duties, responsibilities and qualifications of persons having responsibilities, and protect the rights of shareholders (or member- policyholders) and the interests of policyholders.

Corporate governance can be generally defined as the system by which companies are directed and controlled (Cadbury, 1992). Most of the existing issues apply to all financial institutions also because the OECD guidelines are the basic standard for good practices in corporate governance and focus on "publicly traded companies, both financial and nonfinancial” (OECD, 2004; OECD, 2010).

Corporate governance of banks and insurance companies differs from the corporate governance of other private companies. Banks' stakeholders vary more widely than those of other private companies, including not only pure shareholders, or investors but above all depositors. Banks have some specific 
corporate governance issues; they take and intermediate financial risk to generate revenue and serve their clients, leading to an asymmetry of information, less transparency, and market opaqueness, often also with systemic implications.

Banks can also quickly change their risk profile, so weak internal controls can rapidly cause instability. As a result, sound internal governance for banks is essential, requiring boards to focus even more on assessing, managing, and mitigating risk. Good governance also complements financial supervision and is an integral part of effective riskbased oversight. ${ }^{1}$ The balance sheet of a bank may sometimes be not so easy for outsiders to evaluate the quality of the assets which a bank holds and, therefore, its true financial position. Further, a bank serves several conflicting interests, from equity holders to borrowers or depositors and good governance is important for balancing those interests.

For insurance companies, Solvency II scheme is built on a three-pillar structure which looks to ensure not only adequate financial resources (Pillar 1) but also effective governance by undertakings (Pillar 2) as well as an increased market discipline through disclosure requirements (Pillar 3). Pillar 2 covers corporate governance, the principles for internal control and risk management, the requirements to prepare an Own Risk and Solvency Assessment ("ORSA") and capital add-ons.

Finally, the potential negative externalities of these intermediaries are very damaging for the economy and for society, as was demonstrated vividly by the global financial crisis. In this respect, it is now acknowledged that corporate governance should be addressed with specific recommendations, focusing on "internal governance", strategic and oversight responsibilities of the board and risk management rather than on protection of minority shareholders (BCBS, 2015). This requires a much deeper involvement of the board in strategic issues and risk oversight, as it must fully understand the risks the bank is exposed to and be able to monitor them effectively. Consequently, requirements for balance skills at the board level and the expertise of its members are regulated in detail and closely scrutinized by bank supervisors.

Further, there is greater emphasis and more detailed guidance on the internal control functions of the so-called "second and third line of defence" (risk management, compliance and internal audit), which are mandatory for banks. Due to many traditional and emerging risks inherent to the banking business, which are both financial (e.g. credit, market and interest rate risks) and nonfinancial (e.g., operational, conduct, cybersecurity) in nature, banks are now expected to develop risk appetite frameworks that will help them to control better the aggregate amounts of those risks they are taking in pursuit of their strategy. Banks are also subject to stricter disclosure requirements.

Good corporate governance of banks is particularly important because they are the most

\footnotetext{
The Basel II framework requires that banks maintain strong interna governance procedures and processes. Pillar 2 (supervisory review) in particular requires that banks maintain well-functioning systems of internal controls and risk measurement, management, and mitigation, and adequate processes of review by management and directors.
}

significant (and in some cases only) providers of credit and difficulties in their operations could disrupt the entire economy. In turn, this circumstance puts banks in a unique position to influence the governance practices of their corporate borrowers, thereby reducing risk in their own operations and becoming promoters of better corporate governance practices for all other companies.

The supervisory framework of insurance companies was tested during the 2008 global financial crisis when American International Group (AIG) faced financial uncertainty. The AIG Financial Products unit based in London, a non-insurance component of the AIG holding company system, took on huge losses from risky investments. The contagion effects experienced by U.S. insurers in the AIG holding company system's near-collapse prompted U.S. insurance regulators to re-evaluate their group supervisory framework and pay closer attention to the risks created by activities going on outside of those entities as well as the reputational and contagion issues that could exist.

In the wake of the financial crisis, it became clear U.S. state insurance regulators needed to be able to assess the holding company's financial condition and its impact on an insurer within the holding company system. As a consequence, it was voted to adopt a significant new addition to insurance regulation: the Own Risk and Solvency Assessment (ORSA). An ORSA will require insurance companies to issue their own assessment of their current and future risk through an internal risk selfassessment process and it will allow regulators to form an enhanced view of an insurer's ability to withstand financial stress.

This paper offers an assessment of the corporate governance of Italian banks and insurance companies. The assessment is aimed at providing an overview of the framework governing the corporate governance of these intermediaries and how diligently the various rules and best practice guidelines are implemented.

There were many other important reports with conclusions and emerging good practices and also a great many reports, law reforms, bank supervisory authorities' instructions and recommendations, and codes regarding the corporate governance of banks spread all over the EU member states (OECD, 2009; OECD, 2010; European Commission, 2010). The Basel recommendations, which are drawn up by delegates from many countries, are usually the international forerunners and are taken up by the European Union. They are implemented in the member states either directly or via $\mathrm{EU}$ directives and recommendations.

In literature, many contributions sprang up (Ciancanelli \& Reyes-Gonzales, 2000; Macey \& O'Hara, 2003; Hamalainen, 2004; Mullineux, 2006; Devriese, Dewatripont, Heremans, \& Nguyen, 2004), while the peculiarities of banking and insurance companies corporate governance were critically presented also in specific volumes and papers (Levine, 2004; Kern, Dhumale, \& Eatwell, 2005; Becht, Bolton, \& Roell, 2011).

The financial crisis emphasized that corporate governance of banks and insurance companies is 
special, even if this wasn't evident soon. This was the implicit majority view before the financial crisis, but the special case for the corporate governance of banks and insurance companies was not made until more recently. Since the financial crisis, the insight that these financial intermediaries have special corporate governance problems has gained momentum rather quickly. For the supervisory authorities, it has long been obvious that they should consider corporate governance as part of depositor protection (internal governance).

In general, however, some differences between banks and ordinary firms were counted: liquidityproducing function, leverage, the opaqueness of banks' balance sheets, interbank business, quick changes in risk-profile, runs, systemic risk (Mülbert, 2009; Hopt, 2013b).

The paper aims at considering, even with a qualitative approach, the relationship between the rules and regulations about corporate governance and if successful risk management policies imply good corporate governance. This research question derives from the consideration that banks and insurance companies have a risk-based core business. As mentioned the study is based on a qualitative approach.

The paper is structured as follows: Section 2 presents the relationship between corporate governance and risk governance in banks and insurance companies. Section 3 offers a regulatory framework for corporate governance in financial institutions. Sections 4 and 5 present the traditional corporate governance model adopted by banks and insurance companies. Section 6 offers the main conclusions and policy implications.

\section{RISK GOVERNANCE AS RISK MANAGEMENT IN BANKS AND INSURANCE COMPANIES}

The evolution in the risk environment is creating new governance priorities, and articulating clear mandates around them is an all-important step. Given a more complex and interconnected operating environment, most boards should prepare to question and evaluate the interplay of risks institutions are exposed to as a result of management's business strategy, and probe risks to the bank's chosen strategy. As a corollary, risk committees should challenge the capability of the risk management apparatus to identify, report, and remediate risks relating to strategy.

In this respect, the role of risk oversight and governance goes beyond the notion of mere risk avoidance; it demonstrates how risk committees can help create and protect firm value. In short, the risk committee should take a proactive role in fully appreciating and understanding the nature of risks to which institutions are exposed; re-evaluating or reconsidering the bank's risk strategy and appetite in the context of these new and shifting risks; and reengineering mechanisms to assign accountability and oversee management's execution of risk strategy and appetite.

The health of financial institutions today also reflects the improvement in the risk management process that has been on-going at banks for years. Increasingly, the entire risk management process has become more quantitative, reflecting not only the enhanced ability and lower costs of collecting and processing data but also improved techniques for measuring and managing risk. ${ }^{2}$

Banks have to take risks all the time; banking risks can be broadly classified under 11 categories (Casu, Girardone, \& Molyneux, 2015):

- business/strategic risk;

- compliance risk;

- credit risk;

- cybersecurity risk;

- liquidity risk;

- market risk;

- moral hazard;

- open banking risk;

- operational risk;

- reputational risk;

- systemic risk.

A lack of effective risk governance tops the list of governance failures leading to the crisis. Risk governance is generally defined as board and management oversight of risk and the attendant configuration of internal systems for identifying, measuring, managing, and reporting risk.

While effective risk governance has many elements, it is the board that is ultimately responsible for ensuring that all risks to the bank are identified, evaluated, and suitably managed. Many boards lacked a comprehensive understanding of their institution's risk profile and were unable to judge its appropriateness, in part for the following reasons:

- incomplete risk information was transmitted to boards, leading to a false sense of security;

- there was a fundamental lack of expertise among nonexecutive directors;

- executives used boards as a think function rather than as a forum for verifying strategic risk issues.

There was an overreliance on regulatory and compliance mechanisms to "catch" and report new or inappropriate sources of risk. Lack of timely information for the board due to failures in risk management systems was evidently a problem at several major financial institutions (Dermine, 2013).

In institutions with weak risk governance systems, senior management failed to adopt and integrate the necessary systems to identify, manage, and report risk. The level and nature of aggregate risk arising in rapidly evolving balance sheets were not captured by systems and reports. Risk was not priced properly, either internally or by the market. Return on risk was not accurately reflected or analysed, and as a result, the capital was not properly allocated on the basis of the actual level of business risk. Moreover, funding and liquidity were not properly structured and planned. In some cases, risk measurement systems narrowly focused on readily identifiable or already recognized risks and did not conduct adequate surveillance for other, less obvious and higher-level risks.

Risk management was generally confined to specific arrangements and therefore isolated along

2 The greater use of credit scoring has improved risk management as well. Such tools should perform even better after the effects of the most recent economic slowdown are incorporated. 
with product and organizational lines. Risk management units lacked the visibility, stature, or independence to consolidate institution-wide risks and elevate concerns to a level sufficient to prompt a response from management and the board.

By contrast, banks with good risk governance systems were able to respond with more flexibility. While no financial institution appears to have fully anticipated the magnitude of the crisis, the way in which institutions were able to respond depended in large part on the strength and configuration of their internal risk governance structure. The boards of the institutions better able to consider the emerging problems, generally received timelier, more complete, and enterprise-wide risk information, enabling them to make critical decisions to curtail risk earlier before asset values plummeted and market-based sources of funding became inaccessible.

International organizations and standard setters, including the Organization for Economic Cooperation and Development (OECD), Financial Stability Board (FSB), and Basel Committee on Banking Supervision (BCBS), have launched several reviews on the role of corporate governance in the crisis and have updated their principles and guidelines accordingly. These reviews and revised guidelines generally focus more on effective implementation of existing principles, laws, rules, and codes than on radically different or additional standards.

Many fear that more rigid, prescriptive regulation would result in "form over substance" compliance while failing to achieve better risk governance and more effective board and oversight structures.

Risk management in the insurance business is really particular. On the one hand, insurance companies are selling what many people consider to be risk mitigation. On the other hand, insurance companies themselves face a variety of risks they need to mitigate. Too often, people think insurance is a sufficient, catch-all control activity. But while insurance is a perfect way to protect a business from many risk scenarios, there are other scenarios insurance just can't cover. Oftentimes, insurance does not cover the core competency of a business. Insurance companies can "self-insure" or purchase coverage from a reinsurer, but this doesn't ensure all of the company's risk is accounted for.

According to a recent study (Sirmans \& McCullough, 2017), core risks in the insurance business include "underwriting, credit, market, operational, liquidity risks, etc." Given this wide variety of concerns, there is a great opportunity for risk management in insurance companies to make a positive impact.

Risk management involves identifying, assessing, and mitigating risk. The relevance of a well-implemented risk management program is it's built on a foundation of standardized risk assessments to help companies prioritize their risk based on its potential impact. Naturally, this process will surface risks that will impact the business's core competencies.

A fully integrated enterprise risk management program can help insurance companies develop proactive mitigation activities to protect the core of their business. Insurance companies operate under the increased scrutiny of an ever-changing regulatory environment. Risk managers are expected to fully understand how changes at the local and international impact their organizations, as well as meet customer expectations for substantial coverage with fair requirement and claims processes.

Own Risk and Solvency Assessment (ORSA) requirement is just one example of a changing regulation designed to accommodate regulator and consumer expectations. ORSA is defined as an internal process undertaken by an insurer or insurance group to assess the adequacy of its risk management.

ORSA goes beyond the regulators' disclosure requirements that have universal applicability. It requires firms to "analyze all reasonably foreseeable and relevant material risks that could have an impact on an insurer's ability to meet its policyholder obligations."

The minimum threshold for an ORSA program requires yearly analysis of all material risks. Companies must prove risk assessments have been undertaken at the organizational level where the risk activity takes place, not just at the senior management level. Organizations ensure this occurs by setting a "tone from the top" (Pooser \& Walker, 2015).

ORSA compliance alone can be a major risk management challenge without a connected ERM solution and risk management information system that consolidates information. When any manager can evaluate risks in his or her own sphere of responsibility, however, it's very easy to "roll" assessments up to the next level. Reporting, whether for annual ORSA assessments or a board meeting, becomes a simple matter of presenting information that already exists in the system.

The insurance industry will likely face a changing regulatory landscape in the years ahead. Multiple regulatory influences at the national and international levels continue to present significant challenges for the industry. Risk management enables insurance companies to succeed among this uncertainty by anticipating and addressing a wide variety of change before risk materializes.

\section{REGULATORY RESPONSES TO INCREASING EXPECTATIONS ON GOVERNANCE IN FINANCIAL INSTITUTIONS}

The financial services industry has seen a board of directors (BoD) pushing for enhanced governance frameworks within their organisations. This push for improved governance is not a recent phenomenon. There are also pressures on the board to make such a push. Consequent EU Directives have pushed for increased governance around the internal process. What's more, Regulators aren't the only catalyst for change. The expectations of investors and other stakeholders on governance, especially on listed entities, are increasing.

Stakeholders are more than ever holding the board accountable for the effectiveness of their overall governance process. This shift is real, and it is significant, and is likely to amount to an expectation 
of greater board involvement in the means by which governance is organised and affected. On a structural level, the issue of how to integrate these risks into one single message to senior executives is being addressed (Aebi, Sabato, \& Schmid, 2012). The greater informational asymmetries between insiders and outsiders in banking make it very difficult for diffuse equity and debt holders to monitor bank managers. Controlling owners have incentives to increase the bank's risk profile. Debt holders, however, do not enjoy any upside potential from risk-taking but do on the downside if the bank cannot service its debts. The greater opacity of banks makes it harder for debt holders to control banks from this risk-shifting (Levine, 2004).

These expectations sometimes go down to a product level. This is especially true with the new Regulation drafted following the 2008 financial crisis. Both the Markets in Financial Instruments Directive II (MiFID II) and the Insurance Distribution Directive (IDD) have product governance requirements which factor in board involvement.

Solvency II and Basel III have specific requirements for a "fit and proper" board which conducts proper oversight throughout all the function of the respective bank or insurance company. And whilst this was also required with their precursors, the expectation now is for the board to get their hands dirty and ensure that a proper governance framework is in place.

Even if a number of rules changed after the crisis, regulators are still pursuing reforms through mandatory rules applicable to financial institutions and through enhancements to corporate governance codes applicable to all listed companies. The postcrisis regulatory changes are focusing mainly on remuneration, board composition and independence, shareholder rights and obligations, and risk management.

The European corporate landscape differs both legally and politically and includes different perspectives on governance. In this circumstance, corporate law and codes of governance fall under the scope of individual member states. Since 2000, European authorities have created several initiatives aimed to improve corporate governance standards. While promoting economic growth, the EU is focusing its efforts also in reducing market deficiencies and effectively avoiding unnecessary financial risks of the European economies.

In 2010, the BCBS revised and published a set of principles crucial for effective corporate governance. Safer and more reliable bank functions were the main goal. To ensure that European banks were transparent on risk management and decisionmaking the BCBS developed a principle-based framework in line with the different state governance codes. The objective was to stress the importance of risk management as part of banks' corporate governance framework. Showing the value of a united board, board committees and their corresponding control functions was also a part of the goal. One year later, in September 2011, the European Banking Authority (EBA) also released its own set of internal governance requirements, the Guidelines 44 (EBA GL 44), transposed in Luxembourg in Circular CSSF 12/552. In order to address the potentially detrimental effects of poorly designed corporate governance arrangements on the sound management of risk, and to take into account the new requirements introduced in the CRD in this area, the EBA has updated its Guidelines on internal governance, originally published on 27 September 2011. Those guidelines were revised in September 2017 and new ones entered into effect on 30 June 2018. The previous EBA Guidelines on internal governance (GL44) are repealed on the same date.

The OECD Guidelines on Insurer Governance provide guidance and serve as a reference point for insurers, governmental authorities, and other relevant stakeholders in OECD and non-OECD countries. The Guidelines have been revised and expanded for the second time since they were first adopted in 2005 to reflect evolving market practices and updates to international guidance following the financial crisis (OECD, 2015, 2016). ${ }^{3}$

Weaknesses in corporate governance in a number of institutions have contributed to excessive and imprudent risk-taking in the banking sector, which has led to the failure of individual institutions and systemic problems in Member States and globally.

\subsection{The risk function}

Whilst direct board involvement may be realistic in smaller organizations, larger banks and insurance companies may find these requirements challenging. Such board have generally responded by strengthening internal policies and establishing board-level committees with clear mandates. Roles such as the chief risk officers (CROs) are now common and head well-resourced units which can assist the board in their monitoring work.

In fact, it is now not uncommon, especially in a larger organization, to find individuals with a riskrelated function such as enterprise risk management specialists, compliance officers, internal control specialists, and fraud investigators amongst others. Each would be looking at specific risk areas with the aim of helping the board to manage the different risks which the organization may face.

Risk management involves the management and control bodies, and the various operating units through various roles and responsibilities. There are, at least, four units primarily involved in the management and control of risk:

1) group audit;

2) compliance;

3) asset-liability management (ALM) and liquidity;

4) risk management.

As specifically concerns the management and control bodies involved in risk management, the following have to be considered:

- the board of directors which performs a strategic supervision role, approving the guidelines and strategic approaches for the risk appetite framework (RAF), financial and business plans, budgets, and the policy for risk management and internal control. Every year the board of directors assesses the adequacy of the bank's organisational,

3 The Guidelines complement the principles on pension fund governance in the OECD Core Principles of Occupational Pension Regulation and the G20/OECD Principles of Corporate Governance. 
management and accounting structure, particularly with regard to the internal control system and the management of conflicts of interest;

- the executive committee which is responsible for the day-to-day management of the bank and the coordination and management of the other group companies (if present), except for the tasks reserved to the board of directors;

- the control and risks committee which assists the board of directors by providing advice and information on the internal control system, risk management and the financial reporting structure;

- the statutory audit committee which monitors the risk management and control system as identified by the RAF and the internal control system, assessing the effectiveness of all the structures and units involved and ensuring their coordination.

The following committees have specific powers in the processes of taking, managing, measuring and controlling risks in the risk management system:

- the group risks committee which is tasked with addressing credit, issuer, operational and conduct risks, and with powers of approval for market risks;

- the lending and underwriting committee which has competences for credit, issuer and conduct risk;

- the group ALM and operating ALM committee which monitors group ALM risk-taking and risk management policy (treasury and funding) and approving the methods for measuring exposure to liquidity and interest rate risk and the internal fund transfer rate;

- the investments committee which gives its view on investments and other banking book equity interests;

- the new operations committee which performs an advance assessment of new activities and entry to new sectors and products, and related pricing models;

- the operational risks committee which manages operational risks in terms of risk profile monitoring and identifying mitigation actions.

Yet, the challenge for boards is how to transform the various risk management functions from simply being a corporate function to a discipline which is embedded across the enterprise and viewed as a strategic asset. With this, there also needs to be a shift from a bolted-on, point-specific compliance "solutions" that add costs and headcount to responses that integrate financial, operating, risk, and regulatory requirements. Only through such a transformation, the full benefit of risk management can be obtained.

\subsection{The new internal governance upgrade for banks}

EU legislation requires that institutions have robust governance arrangements, including a clear organizational structure, well-defined lines of responsibility, effective risk management processes, control mechanisms and remuneration policies. The internal governance should be appropriate to the nature, scale and complexity of the institution. The main responsibility for internal governance lies with the management body, which is subject to specific suitability requirements.

According to the new EBA guidelines (EBA, 2017), the role and composition of the management body (i.e. Board of Directors and Executive Committee) and their sub-committees are enhanced, and the governance framework, the risk culture and business conduct, the internal control framework and related mechanisms, the business continuity management and transparency issues are improved.

These Guidelines aim at further harmonizing institutions' internal governance arrangements, processes and mechanisms across the EU, in line with the new requirements in this area introduced in the Capital Requirements Directive (CRD IV) and also taking into account the proportionality principle. Effective internal governance is fundamental if individual institutions and the banking system as a whole are to operate well.

This internal governance upgrade focuses on the entire governance structure. Institutions should take into account their size, internal organization and the nature, scale and complexity of their activities developing and implementing internal governance measures. The number of nominations in the BoD should correspond to the size of the institution.

The role and the composition of the management body and committees are at the basis of how the management body sets, approves and oversees the implementation of a range of different procedures ${ }^{4}$. Then, the governance framework includes the organizational framework and structure, the organization in a group context and the outsourcing policy.

But the topic that is specifically enhanced in the new guidelines is the risk culture and business conduct. The focus is on risk culture, corporate values and code of conduct, conflict of interest policy at the institutional level and for staff, implementation of internal alert procedures (whistleblowing process) and the report of breaches to the competent authorities (Armour et al., 2016).

The internal control framework and mechanisms include frameworks for risk management, internal control functions (risk management, compliance and internal audit) and a new product approval process; and finally, transparency concerns the organization of the management body and the clear distribution of its duties emphasizing the need for communication.

It is evident that the Guidelines put more emphasis on the duties and responsibilities of the management body in its supervisory function in risk oversight, including the role of their committees. They aim at improving the status of the risk management function, enhancing the information flow between the risk management function and the management body and ensuring effective monitoring of risk governance by supervisors.

Financial institutions must have robust governance arrangements, which include a clear organizational structure with well- defined, transparent and consistent lines of responsibility, effective processes to identify, manage, monitor and

4 They can go from business strategies, internal governance and internal control framework to risk and corporate culture. 
report the risks they are or might be exposed to, adequate internal control mechanisms, including sound administration and accounting procedures, and remuneration policies and practices that are consistent with and promote sound and effective risk management.

This new set of internal governance measures wants to ensure the consistency of sound governance arrangements in financial institutions in the EU. It wants to make sure that the main challenges of credit institutions and investments firms on imprudent risk-taking are identified and solved. ${ }^{5}$

In the supervisory function, the BoD is responsible for supervising but also for the decisionmaking process and to challenge the system. Their responsibilities include: monitor and challenge the strategy; oversee and monitor decisions of the management; challenge and review proposals and information provided by the management; fulfil the duties and roles of the risk committee, the remuneration committee and the nomination committee, when such committees have not been set up; assess the effectiveness of the internal governance framework; oversee and monitor that the strategic objectives and risk strategy, including risk management framework and remuneration policy, are implemented correctly; monitor constantly the implementation of risk culture; oversee the integrity of financial information and reporting; ensure that the heads of internal control functions are able to act independently; monitor the implementation of the internal audit plan, after the prior involvement of the risk and audit committees if any.

In its management function, the Executive Committee has specific responsibilities as follows: implement the strategies and discuss regularly their implementation and appropriateness with the BoD; report and inform regularly the BoD of the risks and developments affecting or that might affect the banks. Prudent risk management is based on the adoption of a series of rules, procedures and organisational structures involving the management and the control bodies also of various operating units, if present in the banking structure.

One of the approaches is stood out to risk management based on the principles of prudence and selectivity, in addition to a high level of capitalization.

Risk management is the unit responsible for identifying and implementing an efficient risk management process and for its deployment within the bank. It controls the functioning of the risk management systems of the bank and develops appropriate methods for measuring the overall set of current and future risks. Its task is to provide ongoing control of aggregate exposure to credit, financial, operational and other relevant risks, within the limits set by the internal and supervisory regulations.

\footnotetext{
5 In that respect, the European Central Bank (ECB) developed the Supervisory Review and Evaluation Process (SREP) to guarantee a full and thorough review of the risk profile of an institution and assess the needs of capital and liquidity. The SREP also aims to assess the adequacy of the internal governance and risk management processes of credit institutions, their strategic and capital planning, and the strength of their business models.
}

The head of the unit is the chief risk officer who reports directly to the chief executive officer. He also attends the meetings of the control and risks committee, which he supports in its supervisory work. The risk management unit reports to the control and risks committee and the board of directors twice a year on the work carried out.

The chief risk officer establishes and quantifies the risk appetite, in addition to the risk policies and limits at the operating unit and group level.

To manage the degree of uncertainty inherent in banking and financial activities, we can consider a series of rules, procedures and organisational structures with the aim of:

1) safeguarding the bank's capital strength, with direct benefits for shareholders, customers and employees;

2) supporting the formulation and implementation of business strategies;

3) favouring the sustainable and lasting growth of the bank and returns for shareholders;

4) establishing effective and reliable company processes and procedures.

\subsection{Italian regulation on corporate governance in insurance companies: general considerations}

In July 2017 IVASS opened a consultation on its draft regulation on corporate governance for solo insurance companies and groups, transposing among other things EIOPA's guidelines on this matter pursuant to the Solvency II directive amending Regulation 20/2008 on internal controls, risk management, compliance and outsourcing of insurance activities. The consultation concluded in October, and the publication of the new Regulation, which will abrogate Regulations 20/2008 and $39 / 2011$ and ISVAP circular 574/D of 23 December 2005 on reinsurance liabilities, happened with Regulation 38/2018.

The new Regulation is structured into several main areas, including the system of corporate governance, and in particular the role of corporate bodies, organizational adequacy, the system of internal controls, risk management, and the qualifications of corporate managers and persons performing key functions; the rules on reinsurance and other risk mitigation techniques; the management of corporate capital; the key governance functions, namely risk management, compliance, and internal review, plus the actuarial function; the rules on managerial compensation, designed to strengthen the consistency of pay policies with longer-term objectives and with the primary aim of consumer protection, with the provision for the transmission to IVASS of quantitative data on the compensation of corporate officers and persons performing key functions; the rules on outsourcing, in particular of essential or important activities and key functions; and group corporate governance.

In the course of the consultation, ANIA presented its comments. Among other things, they bore on the eligibility requirements for members of the board of directors, the requirement that the chairman can not be a managing director; 
outsourcing within groups and the centralization of key functions and essential or important functions and activities; key group functions; committees at group level and the role of corporate bodies; the role of key functions within the framework of the corporate governance system; and the calendar for insurers' compliance with the new rules.

Robust systems of corporate governance are necessary for ensuring a strategic vision, adequate counterweights in firms' administration, and sound and prudent management in risk underwriting, measurement and control. ${ }^{6}$ The need to adjust technical provisions, at times to a significant degree, emerged for some firms and groups, as did the need to considerably improve the analyses underpinning the Own Risk and Solvency Assessment (ORSA).

An ORSA is an internal process undertaken by an insurer or insurance group to assess the adequacy of its risk management and current and prospective solvency positions under normal and severe stress scenarios. An ORSA will require insurers to analyse all reasonably foreseeable and relevant material risks (i.e., underwriting, credit, market, operational, liquidity risks, etc.) that could have an impact on an insurer's ability to meet its policyholder obligations (Pooser \& Walker, 2015).

It represents the insurer's "own" assessment of their current and future risks. Insurers and/or insurance groups are required to articulate their own judgment about risk management and the adequacy of their capital position. This is meant to encourage management to anticipate potential capital needs and to take proactive steps to reduce solvency risks. ORSA is not a one-off exercise; it is a continuous evolving process and should be a component of an insurer's enterprise risk management (ERM) framework. Moreover, there is no mechanical way of conducting an ORSA; how to conduct the ORSA is left to each insurer to decide, and actual results and contents of an ORSA report will vary from company to company. The output will be a set of documents that demonstrate the results of management's selfassessment.

The ORSA has two primary goals: 1) to foster an effective level of ERM at all insurers, through which each insurer identifies, assesses, monitors, prioritizes and reports on its material and relevant risk identified by the insurer, using techniques that are appropriate to support risk and capital decisions; and 2) to provide a group-level perspective on risk and capital, as a supplement to the existing legal entity view.

\section{ORGANIZATIONAL AND STRUCTURES IN ITALIAN BANKS}

GOVERNANCE

Italian banks have mainly decided two of the three models proposed for their governance. The first one is the so-called "traditional" management and control system based on the existence of two corporate bodies appointed by the Shareholders'
Meeting: the Board of Directors (BoD), in charge of the strategic supervision and management of the concern, and the Board of Statutory Auditors, responsible for supervising of the management. Legal accounting supervision is entrusted by the Shareholders' Meeting to an external audit firm, on the proposal of the Board of Statutory Auditors, according to current provisions. ${ }^{7}$

This model has proven capable of managing the business efficiently while ensuring effective controls. That is, it creates the conditions for the bank to be able to guarantee the sound and prudent management of complex and global banking groups.

The second model, the "one-tier" system, pursuant to Articles 2409-septiesdecies et seq. of the Italian Civil Code and Articles 147-ter et seq. of the Consolidated Law on Finance, is based on the existence of $\mathrm{a} \mathrm{BoD}$ and a Management Control Committee set up within it, both appointed by the Shareholders' Meeting. The main advantages of the one-tier governance model consist in the centralization of the strategic supervision and management roles in a single body; the integration of the strategic supervision function with the performance of an ex-ante control activity; the enhancing the effectiveness of the control function as centralized in a Committee (the Management Control Committee) established within the Board. ${ }^{8}$

In particular, the centralization of the strategic supervision and management roles in a single body has the following benefits: more direct relationship between the Board, which determines the strategic guidelines and the Managing Director, who proposes and implements them; immediacy in the flow of information, thus saving time and costs; greater interaction and dialogue between those in charge of monitoring the consistency of management with strategic guidelines (the Board as a whole, but especially the non-executive Directors) and the Managing Director (Esposito De Falco, 2014).

\subsection{Internal committees}

The internal committees support, with a proposal, advisory and inquiry tasks, each within its own remit, the board in carrying out its functions, in order to facilitate the adoption of fully informed decisions and increase the efficiency and effectiveness of the board's work.

In both models, in order to foster an efficient information and advisory system to enable the BoD better to assess the topics for which it is responsible, also pursuant to the provisions of the code, the following committees may be established among board members, vested with research, advisory and proposal-making powers diversified by sector of competence Table 1.

\footnotetext{
${ }^{6}$ In 2018 priority was given to verifying how technical provisions an solvency capital requirements are calculated. IVASS identified firms where the administrative bodies needed to improve their risk management and internal audit procedures, and which were not always equipped with the right resources and data to correctly assess technical provisions and solvency capital requirements.
}

\footnotetext{
7 Traditional model is adopted by UniCRedit and MPS.

8 It is adopted by UBI and Intesa SanPaolo since 2016 as before it was adopted the two-tier system.
} 
Table 1. Internal committees

\begin{tabular}{|c|c|c|c|}
\hline Model & Committee & Model & Committee \\
\hline \multirow{4}{*}{ Traditional } & Internal Controls \& Risks Committee & \multirow{4}{*}{$\begin{array}{l}\text { One- } \\
\text { tier }\end{array}$} & Risks committee \\
\hline & Corporate Governance, Nomination and Sustainability Committee & & Nomination committee \\
\hline & Remuneration Committee & & Remuneration committee \\
\hline & Related-Parties and Equity Investments Committee & & $\begin{array}{l}\text { Committee for transactions with } \\
\text { related parties and associated entities }\end{array}$ \\
\hline
\end{tabular}

The two models have small difference above all in the name of the committee, or also in the power which is given to the committee itself. Anyway, the main principle is as follows.

In general, all the committees have been set up in compliance with the provisions contained in the Bank of Italy Supervisory Regulations on banks' corporate governance envisaging three specialist committees for risks, nomination and remuneration, while the committees engaged with Related-Parties, has been set up in compliance with the CONSOB regulatory provisions and the Bank of Italy Supervisory Regulations. If needed the Committees may operate according to procedures considered appropriate and may, inter alia, be split into subcommittees.

The members of the committees for risks must have the knowledge, skills and experience to be able to fully understand and monitor the bank's strategies and risk appetite; at least one member must possess appropriate experience in accounting and finance or risk management, which must be assessed by the $\mathrm{BoD}$ at such time as they are appointed to the Committee.

With a special focus on risk management and control-related issues, the Committee offers a support function to the BoD in:

- defining and approving strategic orientations and risk governance policies with special reference to risk appetite and risk tolerance. For this purpose, it also examines the annual budget drafting guidelines;

- verifying that risk strategies, governance policies and the Risk Appetite Framework (RAF) have correctly been implemented;

defining policies and processes for evaluating corporate activities, including verification that the price and conditions of client operations comply with the risk-related business model and strategies.

The Nomination Committee provides its opinion to the board on defining the self-assessment process, the qualitative and quantitative composition of the board deemed to be optimal, and the number of directorships held in other companies considered compatible with the effective carrying out of the duties in the bank.

Pursuant to the Corporate Bodies Regulations, the Related-Parties Committee's role is to support the BoD providing advice and making proposals. As far as transactions with related and associated parties are concerned, the Committee issues advance and justified opinions, also binding, on the overall adequacy of internal procedures governing the identification and management of transactions with related parties and/or associated parties undertaken by the bank and/or companies, as well as relevant amendments, pursuant to CONSOB Regulation for transactions with related parties, Bank of Italy Regulation for transaction with associated parties and Section 136 of the Legislative Decree n. 385/1993 for transactions with the corporate officers.

\section{GOVERNANCE FOR INSURANCE COMPANIES}

For insurance companies, risk comes in all shapes and sizes. It may stem from a wide variety of sources, including financial uncertainty, legal liabilities, strategic management errors, accidents, and natural disasters. In addition to forecasting financial risks and identifying procedures to avoid or minimize their impact, companies face challenges related to compliance with traditional corporate laws that govern how organizations are structured and managed. Corporate board members are also subject to fiduciary standards that require, among other things, that board members act reasonably and in the best interest of the insurance company and its investors.

Insurers must further comply with state insurance codes, which mandate specific requirements for starting, financing, operating, and winding down insurance operations. Importantly, state insurance laws further impose consumer protection standards, which broaden the scope of liability that insurance companies face under traditional legal principles. Companies must further protect themselves from risks associated with common law causes of action, such as those brought by policyholders for alleged violations of the duty of good faith and fair dealing, which automatically exists by operation of law in every insurance contract.

The adoption of Corporate Governance Regulation, which sets forth corporate governance requirements insurers will need to implement and disclose, has increased the focus on risk and risk management in corporate reporting. The regulation provides that the insurer or insurance group is encouraged to make the corporate governance disclosure at the level at which the insurer's or insurance group's risk appetite is determined. The new reporting requirements imposed will become more significant as more states begin to adopt them. Regardless of whether an insurer does business in a state that has adopted the corporate governance models, the board should analyse its own governance framework and consider whether the company will be ready to comply with the models' reporting requirements once they are adopted.

Because the issues that typically expose a company to the threat of litigation and similar risks often occur at the operational level, the board must ensure that the company's corporate governance framework is structured in such a manner that will foster the free flow of information up the corporate ladder, while also facilitating decision-making at all levels of the organization. In an effort to effectively manage risks, boards should consider adopting an expansive view of corporate governance that focuses on more than the traditional compliance framework that is established by state-based corporate and insurance laws. In addition to adopting a culture of compliance with such laws, it is important to understand how an insurance company carries out its day-to-day business and claims handling practices, as well as how the company processes 
information to adapt to its business environment. In that regard, a corporate governance system should be viewed as information gathering and decisionmaking processes by which information flows from the operating level of an organization up through the chain of command to where decisions are made. Indeed, identification of risk is in many ways a "bottom-up" process.

Boards do not have perfect knowledge of everything that happens within their organizations, but advances in the way boards receive and process information can help improve a company's ability to effectively manage risks. Establishing a corporate governance framework that facilitates the flow of information and promotes decision-making at all levels of the organization can be vital for an insurance company to ensure it has effective processes in place to understand, identify, and manage risks. To do so, it is important to maintain a robust system of reporting mechanisms that allows information to flow from the operating level of the organization to decisions-making bodies, such as board committees. The right people in the organization should be empowered to feed information up, and need to have regular training as to how they are expected to react and what they are expected to report.

Viewed broadly, governance implies not only litigation exposure that typically arises from issues related to corporate control functions and fiduciary duty claims, but also from operational matters, including those related to claims handling and bad faith allegations. Harnessing good information flow and decision-making structures allows isolated pieces of information to be considered in their proper context. For example, an analysis of the company's corporate governance system might reveal information related to particular claims practices and level of corporate review. Such an analysis, along with open channels for allowing lower-level personnel to escalate matters up the chain-of-command, provides a more measured, and potentially more reasonable and defensible, basis for an insurer's claims defence and settlement decisionmaking.

Viewed in the larger governance framework, isolated information that may otherwise be portrayed as problematic from bad faith or claims handling perspective may be addressed by recognizing that the appropriate decision-makers carefully considered all information at issue.

\subsection{The role of internal audit}

Turning to the internal audit function, it also plays a key role within the governance framework. It is the third line of defence reporting directly to the audit committee which ultimately feeds back to the board. Internal audit provides assurance on the effectiveness of governance, risk management, and internal controls, including the manner in which the first and second lines of defence achieve risk management and control objectives.

These functions have a strong impact and influence within the organisation. In fact, EU Directive and Regulations have put Internal Audit as a key function.

The synergy between both functions is the key. For example under Solvency II, insurers are to have both a risk function as part of the second line of defence with internal audit acting as the third line of defence. Both are considered as key functions. This is in line with the three lines of defence model which is the de-facto governance models applied throughout the financial services industry. As already mentioned above, with the myriad of regulation coming into force, having a strong risk function supported by an effective internal audit function is the key.

There are also on-going requirements for risk assessments to be carried out and monitoring of client and employee activity. The work of internal audit will be to support the Compliance function and ensure that all business areas are adhering with the requirements.

Also, an integral part of the risk management system is the policies that outline the principles and guidelines on (i) management of specific risk factors, (ii) management of risk within a specific process, (iii) mitigation of risk and (iv) management of risk measurement models. The risk management system is the set of processes and tools used in support of the risk management strategy of the insurance company; it provides an adequate understanding of the nature and significance of risks to which the company is exposed. The risk management system allows having a single point of view and a holistic approach to risk management and is an integral part of the management of the business. Within the risk management system, the risk management process is articulated in the following stages:

- identification of risks, consisting in the identification of risks believed to be significant i.e. those the consequences of which can endanger the solvency or reputation of the company or be a serious obstacle to the achievement of strategic objectives;

- current and forward-looking assessment of risk exposure is performed through methods envisaged in regulations and best practices as regards risks for which measurement is not regulated or defined by high-level principles. With regard to the forward-looking assessment, the Own Risk Solvency Assessment (ORSA), a system implemented on the basis of principles of completeness, promptness and disclosure efficiency, is used to support the strategic decisions of the company, monitoring of risk exposure and reporting, and ensure a timely and on-going monitoring on the evolution of the risk profile and the compliance of the risk appetite identified. This system guarantees that the quality and quantity of information provided is commensurate with the needs of the different recipients and with the complexity of the business managed, in order for it to be used as a strategic and operating tool in assessing the potential impact of decisions on the company's risk profile and solvency;

- mitigation of risks, which consists in identifying and proposing actions and interventions required and/or useful in mitigating existing or prospective levels of risk not in line with the risk objectives defined at the corporate level.

The risk identification, assessment and monitoring processes are performed on an on-going basis, to take into account any changes in their nature, business volumes and market context, and the insurgence of new risks, or changes in existing risks.

The challenge that both of these functions face, and which ultimately have an impact on their strength and effectiveness within the organisation, is to have skills which remain relevant as organisations grow and develop. Whereas before the skills were focused on an understanding of the operational framework, controls and audit methodologies, IT- 
focused knowledge is now required. Regulations such as the General Data Protection Directive (GDPR), which impacts all Financial Services firms, clearly requires a team of individuals from a risk and internal audit background with both operational and IT risks and controls knowledge.

\section{CONCLUSION}

The paper aims to examine the connections between risk management policies and corporate governance as a basic risk for effective strategies in banks and insurance companies. The paper takes as a starting point the rules and regulations by EBA and EIOPA and the existing literature on corporate governance, in order to create a theoretical model of an efficient internal control system.

The paper focuses mainly on the relationship between risk management and corporate governance. Further research could concern the relationship with other functions and the regulations of other countries.

As results of the research there is the consideration that if regulators define their rules by taking into account the presence of internal risk culture, we maintain that the improvement of corporate governance is the only way to reach a better risk control. There are cooperation forms between the internal control system functions.

This subject has not been analysed in-depth to date. This article attempts to obtain an identification of the roles and responsibilities of the main functions involved in the risk management system in order to define organizational models characterized by the complementarity of interventions and thus oriented towards the objectives of effectiveness and efficiency.

It is clear that it may not be enough for various risk and internal audit functions to be present within an organization. There are challenges for the Board and Senior Management who need to assign specific roles and effectively coordinate the roles of both functions. This is the key to ensure that there are neither "gaps" in controls nor unnecessary duplication of work.

Clear responsibilities must be defined so that each function understands the boundaries of their responsibilities and how their position fits within the organization's overall risk and control structure. Without a cohesive, coordinated approach, limited resources may not be deployed effectively, and significant risks may not be identified or managed appropriately. With the variety of threats faced by financial services organization, internal weaknesses may pose an increased risk. The resulting consequences would be too high to ignore.

Corporate governance is indeed one of the cornerstones of a properly functioning corporate sector and the financial and economic system. Effective implementation of sound corporate governance requires relevant regulatory and institutional foundations. Factors, including the system of business laws, stock exchange rules and accounting standards, can affect market integrity and systemic stability.

While studies and reviews document several governance failures, one common conclusion is that much of the existing governance framework is generally adequate and should remain intact, even if with details of implementation. A key priority is to increase the capacity of boards to oversee strategic risk-taking and to accurately judge institutional performance.

Improving board capacity will require upgrading the skills, experience, and leadership of nonexecutive directors and rebalancing the productive tension that should come with a highperforming board. Shareholders, particularly longerterm institutional investors, can play a role in this respect through more responsible interaction with the boards and a focus beyond short-term returns that might compromise longer-term safety and soundness.

The most obvious governance-related policy responses have accompanied government support to troubled financial institutions. In addition, international organizations and standard setters are updating their principles and guidelines, focusing more on the effective implementation of existing rules than on radically different or additional standards. Governments and regulators are also pursuing reforms, both through mandatory rules applicable to financial institutions and through enhancements to corporate governance codes applicable to all listed companies. Reforms are expected in executive remuneration, board independence and composition, and risk governance structures.

To that end board members should prepare for these changing expectations with the operating principle of presenting an effective challenge to management across the breadth of strategic issues. To meet and exceed the expectations, board members should focus on creating robust information flow structures (especially around emerging risks) actively empowering the independent risk management function, and keeping pace with growing complexity in the risk environment.

Cognitive "silos" will need to disappear in every direction. Risk management logic should permeate all aspects of banking and insurance activity. The top management will have to define the objectives in relation to two dimensions: profitability and risk jointly for the entire business. It will need to assess the possibility of their attainment in probabilistic terms in order to understand whether it is giving its resources excessively challenging or feasible objectives; lastly, it will need to configure the intervention or recovery actions to be implemented as preventive measures when things are not moving in the right direction due to the action of the competition or owing to the change in economic and financial scenarios.

The analysis developed in the paper must be obviously considered only as a first step about the improvement of the internal governance policy of banks and insurance companies.

\section{REFERENCES}

1. Adams, R. B. (2012). Governance and the financial crisis. International Review of Finance, 12(1), 7-38.

2. Aebi, V., Sabato, G., \& Schmid, M. (2012). Risk management, corporate governance, and bank performance in the financial crisis. Journal of Banking and Finance, 36, 3213-3226.

3. Anderson, R. C., \& Fraser, D. R. (2000). Corporate control, bank risk taking, and the health of the banking industry. Journal of Banking \& Finance, 24(8), 1383-1398.

4. Armour, J., Awrey, D., Davies, P. L., Enriques, L., Gordon, J. N., Mayer, C., \& Payne, J. (2016). Bank governance.

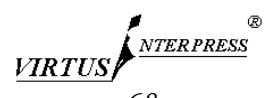


Principles of financial regulation (European Corporate Governance Institute (ECGI) - Law Working Paper No. 316). Retrieved from https://ssrn.com/abstract=2793112

5. Baranoff, E. G., \& Sager, T. W. (2009). Do life insurers' asset allocation strategies influence performance within the enterprise risk framework? The Geneva Papers on Risk and Insurance - Issues and Practice, 34(2), 242-259. https://doi.org/10.1057/gpp.2009.5

6. Basel Committee on Banking Supervision (BCBS). (2006). Enhancing corporate governance for banking organizations. Retrieved from https://www.bis.org/publ/bcbs117.pdf

7. Basel Committee on Banking Supervision (BCBS). (2010). Principles for enhancing corporate governance. Retrieved from https://www.bis.org/publ/bcbs176.pdf

8. Basel Committee on Banking Supervision (BCBS). (2015). Corporate governance principles for banks. Retrieved from https://www.bis.org/bcbs/publ/d328.pdf

9. Becht, M., Bolton, P., \& Roell, A. (2011). Why bank governance is different. Oxford Review of Economic Policy, $27(3), 437-463$.

10. Berger, A. N., Kick, T., \& Schaeck, K. (2014). Executive board composition and bank risk taking. Journal of Corporate Finance, 28, 48-65.

11. Cadbury, A. (1992). Report of the Committee on the Financial Aspects of Corporate Governance. London, England: Gee.

12. Casu, B., Girardone, C., \& Molyneux, P. (2015). Introduction to banking (2nd edition). Harlow, England: Pearson.

13. Ciancanelli, P., \& Reyes-Gonzales, J. A. (2000). Corporate governance in banking: A conceptual framework. Retrieved from http://papers.ssrn.com/ abstract $=253714$

14. Dermine, J. (2013). Bank corporate governance, beyond the global banking crisis. Financial Markets, Institutions \& Instruments, 22(5), 259-318.

15. Devriese, J., Dewatripont, M., Heremans, D., \& Nguyen, G. (2004). Corporate governance, regulation and supervision of banks. Financial Stability Review, National Bank of Belgium, 2(1), 95-120.

16. EBA. (2017). Guidelines on internal governance under Directive 2013/36/EU. Retrieved from https://eba.europa.eu/ documents/10180/1972987/Final+Guidelines+on+Internal+Governance+\%28EBA-GL-2017-11\%29.pdf

17. EIOPA. (2018). Solvency II Guidelines on system of governance. Informal advice by the EIOPA Insurance and Reinsurance Stakeholder Group. Retrieved from https://eiopa.europa.eu/Publications/Administrative/IRSG-201825_IRSG_Advice_System_of_Gov_GL.pdf

18. Eling, M., \& Marek, S. (2011). Corporate governance and risk taking: Evidence from the U.K. and German insurance markets (Working paper on risk management and insurance, 103, Institute of Insurance Economics). Retrieved from https://www.ivw.unisg.ch/ /media/internet/content/dateien/instituteundcenters/ivw/wps/wp103.pdf

19. Eling, M., \& Schmeiser, H. (2010). Insurance and the credit crisis: Impact and ten consequences for risk management and supervision. The Geneva Papers on Risk and Insurance - Issues and Practice, 35(1), 9-34. https://doi.org/10.1057/gpp.2009.39

20. Esposito De Falco, S. (2014). La corporate governance per il governo dell'impresa. Milan, Italy: McGraw-Hill education.

21. European Banking Federation (EBF). (various years). Banking in Europe: EBF facts \& figures. Retrieved from https://www.ebf.eu/facts-and-figures/

22. Fekadu, G. W. (2015). Corporate governance on financial performance of insurance industry. Corporate Ownership \& Control, 13(1-10), 1201-1209. https://doi.org/10.22495/cocv13i1c10p7

23. Financial Stability Board. (2013). Thematic review on risk governance. Retrieved from https://www.fsb.org/wpcontent/uploads/r_130212.pdf

24. Hagendorff, J. (2014). Corporate governance in banking. In A. N. Berger, P. Molyneux, \& J. O. S. Wilson (Eds.), The Oxford handbook of banking (2nd ed.). Oxford, England: Oxford University Press.

25. Hamalainen, P. (2004). Mandatory subordinated debt and the corporate governance of banks. Corporate Governance: An International Review, 12(1), 93-106.

26. Hopt, K. J. (2013a). Better governance of financial institutions (ECGI Working Paper Series in Law; Working Paper $\left.\mathrm{N}^{\circ} .207 / 2013\right)$.

27. Hopt, K. J. (2013b). Corporate governance of banks and other financial institutions after the financial crisis. Journal of Corporate Law Studies, 13(2), 219-253. https://doi.org/10.52 35/14735970.13.2.219

28. Kern, A., Dhumale, R., \& Eatwell, J. (2005). Global governance of financial systems: The international regulation of systemic risk. Oxford, England: Oxford University Press.

29. Levine, R. (2004). The corporate governance of banks: A concise discussion of concepts and evidence (Policy Research Working Paper No. 3404). Retrieved from https://openknowledge. worldbank.org/handle/10986/14239

30. Macey, J. R., \& O'Hara, M. (2003). The corporate governance of banks. Economic Policy Review, 9(1), 91-107.

31. Mülbert, P. O. (2009). Corporate governance of banks after the financial crisis - Theory, evidence, reforms (ECGI Law Working Paper, No. 130). Retrieved from https://ecgi.global/sites/default/files/working_papers/documents/ SSRN-id1448118.pdf

32. Mullineux, A. (2006). The corporate governance of banks. Journal of Financial Regulation and Compliance, 14(4), 375-382.

33. Mullineux, A. (2007). Financial sector convergence and corporate governance. Journal of Financial Regulation and Compliance, 15(1), 8-19.

34. OECD. (2004). OECD principles of corporate governance. Retrieved from https://www.oecd. org/daf/ca/corporategovernanceprinciples/31557724.pdf

35. OECD. (2009). Corporate governance and the financial crisis: Key findings and main messages. Retrieved from https://www.oecd.org/corporate/ca/corporategovernanceprinciples/43056196.pdf

36. OECD. (2010). Corporate governance and the financial crisis: Conclusions and emerging good practices to enhance implementation of the principles. Retrieved from http://www.oecd.org/corporate/ca/corporategovernance principles/44679170.pdf

37. OECD. (2015). G20/OECD principles of corporate governance. Retrieved from https://www.oecd-ilibrary.org/doc server/9789264236882-en.pdf? expires=1576504550\&id=id\&accname=guest\&checksum=DADC3FB90B19D827 0219B01F85A8783E

38. OECD. (2016). Core principle of occupational pension regulation. Retrieved from http://www.oecd.org/daf/fin/ private-pensions/core-principles-private-pension-regulation.pdf

39. Pooser, D. M., \& Walker, P. L. (2015). Own risk and solvency assessment: Origins and implications for enterprise risk management. Journal of Insurance Regulation, 34(9), 1-27.

40. Sirmans, E. T., \& McCullough, K. A. (2017). A comparison of the risk management and own risk and solvency assessment model act and insurer ratings. Journal of Insurance Regulation, 36(3), 1-32. 